\title{
A LEI DE RESPONSABILIDADE FISCAL E SEUS PRINCÍPIOS JURÍDICOS ${ }^{1}$
}

\author{
Diogo DE FigueIREdo MoreIRA Neto ${ }^{2}$
}

"A anarquia está em toda parte quando a responsabilidade não está em parte alguma."

GUSTAVE LE BON

1. Introdução - 2. Os novos princípios - 3. Alguns elementos sobre os principios jurídicos - 4. Principios informativos do direito financeiro - I - Princípios Fundamentais - 1. Princípio Republicano - 2. Princípio Democrático - 3. Princípio Participativo - II - Princípios Gerais - 1. Princípio da Legalidade - 2. Princípio da Legitimidade 3. Principio da Impessoalidade - 4. Princípio da Moralidade Administrativa - 5. Princípio da Eficiência - 6. Princípio da Continuidade 7. Princípio da Publicidade - III - Princípios Setoriais - 1. Princípio do Planejamento - 2. Princípio do Equilíbrio - 3. Princípio do Controle - 4. Princípio da Responsabilidade - 5. Princípio da Responsividade - 6. Conclusões

\section{Introdução}

A globalização das atividades econômicas pôs em evidência as diferenças e as debilidades dos diferentes sistemas governamentais existentes com relação à qualidade de desempenho, notadamente quanto à segurança das atividades dos agentes econômicos que neles atuam.

1 Exposição apresentada no Seminário realizado pela Escola da Magistratura do Estado do Rio de Janeiro e pela Procuradoria Geral do Estado do Rio de Janeiro, em 5 de julho de 2000, sobre a Lei Complementar $\mathrm{n}^{\circ} 101$, de 4 de maio de 2000 .

2 Procurador do Estado do Rio de Janeiro, Professor Titular de Direito Administrativo da Universidade Cândido Mendes, Professor da Escola da Magistratura do Estado do Rio de Janeiro e Diretor do Instituto Atlântico.

R. Dir. Adm.,

Rio de Janeiro, 221: 71-93, jul./set. 2000 
Com efeito, o adensamento dos negócios e, notadamente, dos investimentos internacionais, tão essenciais para o desenvolvimento, deflagraram uma sadia competição entre os Estados para que proporcionem não apenas menores custos de transações, como as condições mínimas de confiabilidade e de eficiência capazes de gerar confiança nas transaçōes.

Para este efeito, a competição econômica entre países e blocos de países depende, além dos custos fiscais, cada vez mais, da imagem de segurança e de equilíbrio, de que gozam seus respectivos governos, aqui entendidos em seu sentido mais amplo, incluindo todas as manifestações orgânico-funcionais de poder estatal.

Sob este último aspecto, certas atividades do Poder Público são particularmente mais sensíveis para atrair e manter negócios, como as relativas à confiabilidade da Justiça, às garantias tributárias e à estabilidade monetária, e que mais pesam no conceito de risco soberano, que vem a ser a álea das transações econômicas que não depende senão do comportamento do Estado em sua atuação, positiva ou negativa, e, por conseqüência, no chamado custo-país.

Por essas razões, a redução do risco soberano e o conseqüente incremento da confiabilidade nas instituiçôes de cada País, já estão levando a uma revisão das causas do subdesenvolvimento econômico, num mundo em que a transparência das instituições é inevitável.

Com efeito, a correta identificação da vulnerabilidade financeira de um País poderá ser um fator de peso igual ou maior do que os clássicos, a matéria prima e a mão-de-obra baratas, ou dos fatores que mais recentemente a eles se somaram ou, quiçá, já os substituem, como a tecnologia e mercadologia superiores, pois todas essas vantagens podem não ser compensadas pelos riscos de transações processadas com baixo nível de segurança juspolítica.

Ora, é inegável que entre as principais causas de insegurança institucional de um país, estão as relacionadas à moeda e às finanças públicas, uma vez que a má gestão, nesses dois setores da administração pública, é a via para os endividamentos públicos insuportáveis e para a inflação descontrolada, além de escancarar as portas para a fuga de capitais e de cérebros e de estimular a proliferação do vírus da corrupção.

A condução correta e responsável das finanças públicas, que é a que se processa através das boas técnicas do orçamento e da gestão financeira e, sobretudo, pelo cultivo da responsabilidade fiscal, é o antídoto adequado para esses males e o caminho certo para a afirmação da seriedade dos vários níveis de governo de um País e para o estabelecimento de sua confiabilidade como ambiente de negócios.

Infelizmente, o trato do orçamento e das finanças públicas, em satisfatório nível de qualidade, no Brasil sempre deixou muito a desejar. Embora o orçamento tenha sido aqui introduzido de há muito, em sua versão inglesa, original, como instrumento de acompanhamento do desempenho da gestão financeira (performance budget), e, mais recentemente, em sua versão norte-americana, mais moderna, como instrumento de planejamento e programação da gestão financeira (planning and programming budget), esse instituto jamais chegou a ser adequada e corretamente utilizado, e, muito menos, voltado a satisfazer os seus mais elevados alcances políticos. 
Com efeito, entre nós, a Administração financeiro-orçamentária, habitualmente, se reduzia à montagem de simulações de orçamentos, por vezes tão rústicas e grosseiras, que é possível aludir-se a um mito orçamentário, como um das principais barreiras, opostas pela praxis política, à desejável gestão racional legal e legítima das finanças públicas; isso desde a União ao menor dos Municípios.

Ora, o mito do orçamento introduz, na gestão das finanças públicas, o arbítrio e a insegurança, constituindo-se numa espantosa e inexplicável exceção ao Estado de Direito, e, em última análise, a negação dos mais relevantes princípios sobre os quais se assentam as organizações políticas contemporâneas. Mas, uma gestão arbitrária das finanças públicas vem a ser, sobretudo, o cínico falseamento da democracia e a traição institucionalizada da vontade popular, como prática contumaz, dos gestores políticos da coisa pública, que, não obstante, invariavelmente, se jactam de reverenciá-las.

Diante desse quadro, recuperar o instrumento orçamentário, ou seja, torná-lo real, e suportá-lo com regras rigorosas de gestão responsável, nesta quadra de acelerada modernização institucional e na corrida do progresso dos povos, só poderia ser prioridade absoluta dos legisladores brasileiros.

Somente através da restauração da realidade orçamentária, podem ser controlados e até reduzidos em níveis suportáveis os três vilões das finanças públicas: o déficit público, que ocorre quando os governos gastam mais do que arrecadam; a divida pública, que é a expressão do déficit que se transfere de um orçamento para o outro, prejudicando novos programas que poderiam ser executados; e o endividamento público, que se instala, cronicamente, no processo de acumulação da dívida pública e passa a absorver cada vez mais recursos públicos para seu serviço e amortização.

Esses três vilões - déficit, dívida e endividamento públicos - sobreviveram e prosperaram, alimentados por hábitos financeiros atrasados e nocivos, de prática comum na Administração Pública brasileira, mantidos pela baixa qualidade e, sobretudo, pela irresponsabilidade de gestores públicos, que não estão preocupados com eficiência administrativa, mas com sua "eficiência" eleitoreira, na condução de práticas patrimonialistas paternalistas e demagógicas.

É bem verdade que a melhor sanção para essa irresponsabilidade política deveria ser o "veto eleitoral" do cidadão, pois, como bem argumenta Adilson Abreu Dallari, "A mais severa punição ao agente político despreparado, irresponsável ou corrupto deveria ser aplicada no momento do voto, mas o sistema político eleitoral favorece a demagogia e o abuso do poder econômico ou político, viciando a vontade do eleitor e, consequientemente, o sistema representativo. Tudo isso leva a que as pessoas de bem se desinteressem dos assuntos políticos e até mesmo se afastem da atividade pública." 3

Mas mesmo enquanto não é alcançado o almejado desenvolvimento integral, que seria a solução definitiva, é preciso reverter a expectativa, reforçando os institutos da responsabilidade, para afastar a idéia de que a conduta politicamente irres-

3 ADILSON ABREU DALLARI, A Responsabilidade do Agente Político, artigo in Jus Navigandi, Doutrina, http://www.jus.com.br, setembro de 1999, p. 4. 
ponsável não é punida, pois a impunidade, como se sabe, é o maior incentivo às transgressões e, no caso dos agentes políticos, "é tomada como algo inerente à atividade governamental. Levar vantagem por meio do sacrifício alheio. Parece ser algo totalmente indissociável do exercício do poder". ${ }^{4}$

Assim, restaurar o orçamento-realidade, recuperar a gestão-seriedade, pela institucionalização de novos e rigorosos padrões de responsabilidade, tudo em benefício da higidez do sistema financeiro público brasileiro, tornou-se o desafio enfrentado na longa elaboração da Lei Complementar $n^{\circ} 101$, de 4 de maio de 2000 , a que se acresce, hoje, o de conferir-lhe efetividade.

Para essa tarefa, reconhecidamente muito difícil, não só pelas dificuldades opostas pelas referidas deformações da prática política brasileira, como pela complexidade dos novos conceitos jurídicos e técnicos introduzidos, de muito servem os precedentes desenvolvidos pelas organizações internacionais e pelos países que os adotaram.

São bons exemplos, o estudo amplamente divulgado pelo corpo técnico do Fundo Monetário Internacional, definindo uma declaração de princípios da cidadania para as boas práticas de transparência fiscal, bem como as experiências recolhidas nas legislações financeiras da Nova Zelândia e da Argentina, esta, particularmente, com sua lei consolidadora $\mathbf{n}^{\circ} 24.156$, de 26 de outubro de 1992.

Mas, acima de tudo, para que se logre êxito na compreensão e na aplicação de todas as alterações introduzidas, é mais importante desenvolver a consciência da necessidade de evoluir na linha dos princípios regedores da administração financeira pública e de bem compreendê-los, para passar a vivenciá-los, como uma nova moldura juspolítica para uma nova era da gestão da coisa pública no País.

\section{Os novos princípios}

Parte-se do antigo trinômio - república-legalidade-responsabilidade, para chegar a este novo, que não o substitui, senão que a ele se acresce, elemento a elemento, o trinômio - democracia-legitimidade-responsividade.

É, fundamentalmente, a mesma linha evolutiva que dita a passagem do Estado de Direito para o Estado Democrático de Direito.

Com efeito, para o Estado de Direito, bastava o princípio republicano, e mais os seus conexos, da legalidade e da responsabilidade, para travejar sua administração financeiro-orçamentária.

O princípio republicano, afirmando a existência de "coisas públicas", entregues à gestão do Estado, em lugar de "coisas do rei", que as geriria em benefício do povo, sob o princípio regaliano.

O princípio da legalidade, afirmando o desempenho da gestão de acordo com a vontade vinculada do Estado, expressa na lei, em lugar da vontade arbitrária do soberano, expressa em seus comandos. 
O princípio da responsabilidade, necessária derivação, submetendo os atos de gestão e a própria pessoa do gestor público a sanções, no caso de infringir a lei.

$\mathrm{O}$ advento do Estado Democrático de Direito, na feliz designação dos constituintes de Bonn, acrescentaria, no Segundo Pós-Guerra, três novos princípios: o democrático, e os seus conexos, o da legitimidade e o da responsividade, em complementação biunívoca dos três anteriores: o democrático, complementando o republicano; o da legitimidade, complementando o da legalidade; e o da responsividade, complementando o da responsabilidade.

As mudanças são perceptíveis.

O princípio democrático acrescentou que as "coisas públicas", não são realmente "públicas", no sentido patrimonial, mas no sentido utilitário, porque ao Estado cabe apenas geri-las em benefício de todos, segundo a vontade de todos.

O princípio da legitimidade firmou que não basta que a gestão da coisa pública se faça de acordo com a vontade da lei, porque também é necessário que produza os resultados pretendidos pela própria vontade democrática, que vocacionou legalmente a sua utilidade.

O princípio da responsividade, por derradeiro, e de todos o mais recente, asseriu a necessidade de aplicar sanções sobre os atos de gestão e sobre a própria pessoa dos gestores, que deixem de reagir logo e adequadamente às diretrizes, que incorporam a vontade legítima, democraticamente manifestada.

Como se procurará demonstrar neste breve ensaio, a Lei de Responsabilidade Fiscal dá este grande passo, no sentido de tornar efetivo, no campo das finanças públicas, o que apenas ficara implicitamente prometido pelo legislador originário, em 1988, ao proclamar a constituição de um Estado Democrático de Direito, na frontada de seu trabalho.

Se essa Lei logrará ou não mudar os velhos hábitos e se será ou não cumprida, serão desafios à maturidade político-administrativa do País, pois maturidade não consiste em fazer boas leis, mas em respeitá-las.

Não haja dúvidas de que se está diante de importantes desafios para o futuro do País, do qual não podem refugir os profissionais de Direito, que devem zelar, em seus diferentes, mas convergentes, ministérios jurídicos, pela boa interpretação da nova Lei e por seu rigoroso cumprimento, tarefas ambas, para as quais são imprescindíveis o travejamento e o alumbramento, que, sempre mais, os princípios de direito podem proporcionar aos ordenamentos jurídicos pós-positivistas.

É neste sentido e com esta finalidade, pois, de avançar na principiologia da nova gestão financeiro-orçamentária da coisa pública no Brasil, que se alinham estas reflexões, com a pretensão de serem provocativas e de aflorarem novos veios à garimpagem jurídica.

\section{Alguns elementos sobre os princípios juridicos}

Auspiciosamente, já se vai tornando desnecessário motivar o estudo dos princípios do direito, depois que as grandes mudanças no pensamento filosófico, político e jurídico das últimas décadas do século XX voltaram-se a recuperar os valores 
substantivos da conduta humana e a repor os valores formais na função, que lhes cabe, de instrumentos.

A importância e o emprego dos princípios, na política e no direito, acompanham essa evolução, na medida em que, com eles, se vão explicitando valores, como vem ocorrendo com os próprios textos constitucionais, e nos dá conta Vezio Crisafulli, que tem observado o fenômeno em profundidade desde o termíno da Segunda Guerra Mundial e, até mesmo, como uma resposta do espírito humano aos horrores que trouxeram as conflagrações e as ideologias radicais. ${ }^{5}$

Com efeito, o Direito, tanto como qualquer outra Ciência, não prescinde de princípios, que lhe conferem coerência e sistemática, qualidades imprescindíveis para que qualquer conjunto de conhecimentos integrado adquira o status científico.

Os princípios são abstraçōes de segundo grau, por serem abstrações inferidas das leis, no sentido epistemológico, que, por sua vez, são abstrações ditas de primeiro grau, porque se desumem diretamente dos fatos, para evidenciar alguma invariância que os caracterize.

Princípios e leis, guardando ainda, para estas, o seu sentido epistemológico, em que estão sendo tratadas, são, ambos, normas, inferidas, indiferentemente, da realidade ou da idealidade, ou seja, do ser ou do dever ser.

Essa distinção define, conforme o caso, na conhecida classificação de Dilthey, de um lado, o campo das Ciências da Natureza, com suas invariâncias mais rigorosas e invulneráveis, enquanto não infirmadas, e, de outro, o campo das Ciências do Espírito, com suas invariâncias menos rigorosas, porque são por natureza vulneráveis, mesmo que não sejam infirmadas em seu valor, embora, hodiernamente, observem-se numerosas superposições, que concorrem para esbater as fronteiras entre os dois campos.

São, portanto, os princípios e as leis do ser, de natureza explicativa, normas das Ciências naturais, enquanto os princípios e as leis do dever ser, são de natureza preceptiva, normas das Ciências humanas, entre as quais se situa enciclopedicamente a Ciência do Direito.

Todavia, no Direito, as normas podem se apresentar, concretamente preceptivas ou abstratamente preceptivas.

Concretamente preceptivas serão as normas que imponham preceitualmente uma conduta ou condutas determinadas, desde que contenham elementos suficientes para identificar as circunstâncias em que são aplicadas e os efeitos desta aplicação.

Abstratamente preceptivas, distintamente, serão as normas que não imponham preceitualmente qualquer conduta determinada, uma vez que lhes faltam os elementos suficientes para identificar as circunstâncias em que deverão se aplicar e os efeitos de sua aplicação.

As normas concretamente preceptivas, que, na concepção dogmática de origem tedesca, são as que se encontram suficientemente densificadas em seu conteúdo expositivo, para serem imediata ou mediatamentamente referidas e aplicadas às

5 VEZIO CRISAFUlli, La Costituzione e le sue Disposizioni di Principio, Milão, Dott. A. Giuffrè, 1952. 
condutas humanas, são as leis preceituais ou simplesmente, preceitos, ou, ainda, regras (como prefere Gomes Canotilho).

As normas abstratamente preceptivas, na mesma orientação teorética, são as que requerem densificação de seu conteúdo expositivo através de outras normas, para descer aos fatos, identificá-los e regrar determinadas condutas a eles referentes, são os princípios.

Mas, por serem normas jurídicas, tanto os preceitos (ou regras) jurídicos, quanto os princípios jurídicos, hão de produzir ambos, necessariamente, algum tipo de eficácia no mundo do Direito, embora com diferentes amplitudes e intensidades.

Há, portanto, uma importante diferença de conteúdo entre esses dois tipos de normas examinadas, pois, enquanto a lei jurídica (preceito ou regra) é predominantemente preceptiva de uma espécie de conduta humana concreta, o princípio jurídico é predominantemente indicativo de um gênero de condutas, que serão concretamente prescritas pelas leis que dele derivem.

Dai definir-se, sinteticamente, o principio juridico, como norma indicativa, uma vez que sua principal finalidade é apenas a de indicar um valor ou um fim, que devam ser genericamente alcançados, não importa em que grau satisfativo, por todas as leis (preceitos ou regras jurídicos), normas concretamente preceptivas, que deles se derivem.

Resulta nítida, dessa conceituação, a importância estruturante dos princípios, uma vez que a infraestrutura de normas preceptivas se articula polivalentemente com uma superestrutura de normas principiológicas, que lhes conferem sentido valorativo e finalístico, e lhes dão toda coerência sistêmica necessária para aplicá-las harmonicamente.

Como os princípios são as normas portadoras dos valores e dos fins genéricos do Direito, em sua forma mais pura, explica-se porque sua violação tem repercussão muito mais ampla e grave do que a transgressão das normas preceituais, que os aplicam às espécies definidas pelos legisladores, venham ou não, tais princípios, expressos explicitamente na ordem jurídica, bastando que nela sejam expressos implicitamente.

Todavia, a positivação de um princípio é sempre benéfica e desejável, sobretudo por produzir um efeito irradiante, de abertura sistêmica, de elevadíssimo cunho didático-pedagógico, ao dar relevo e nitidez aos valores e fins que porta.

Quanto às várias eficácias possíveis, ou funções que podem desempenhar os princípios, há várias classificações, dos mais notórios autores que delas trataram, como é o caso de Robert Alexy, de Gomes Canotilho e, entre nós, de Luís Roberto Barroso e de Ruy Samuel Espíndola, para não alongar uma enunciação que poderia alcançar umas duas dezenas de nomes, neles incluído o meu próprio. ${ }^{6}$

Simplificadamente, uma classificação dicotômica distingue, desde logo, dois tipos de eficácia dos princípios: uma eficácia imediata, impeditiva de conduta, que

6 A referência é a uma classificação proposta em breve ensaio sobre Princípios da Licitaçāo, publicado em julho de 1995, in Boletim de Direito Administrativo, São Paulo, Nova Dimensāo Jurídica, $\mathrm{n}^{\circ} 7$, ano XI. 
prescinde da existência de preceitos deles derivados, e uma eficácia mediata, indicativa de conduta, porque demanda a existência de preceitos deles derivados.

A eficácia imediata, todos os princípios a têm e no mesmo grau, obstando que produzam efeito, na mesma ordem jurídica em que eles se entronizam, quaisquer preceitos ou atos aplicativos concretos que sejam com eles antagônicos. No conflito entre um princípio e um preceito com ele incompatível, o preceito é afastado, não só para desaplicá-lo, no todo ou, se possível, apenas na parte incompatível, como para invalidar os efeitos que vulnerarem a norma principiológica, ${ }^{7}$ destacando-se as seguintes:

1. A eficácia dirimente, que consiste em suprimir a produção de efeitos de quaisquer normas ou atos concretos que sejam incompatíveis com o conteúdo de valor contido no princípio.

2. A eficácia impediente, ou redutora, que consiste em impedir em parte ou em condicionar, a produção de efeitos de quaisquer normas ou atos concretos que sejam parcialmente incompatíveis com o conteúdo de valor contido no princípio.

A eficácia mediata é aquela que o princípio repassa, por sua vez, a toda a ordem jurídica, através dos preceitos e dos atos aplicativos concretos que neles se informem, destacando-se, entre outras, as seguintes:

1. A eficácia axiológica, que consiste em definir com clareza, na ordem jurídica, os valores que a informam.

2. A eficácia nomogenética, que consiste em dar fundamentos finalístico-valorativos para a edição de novos preceitos e de neles reproduzir esse conteúdo.

3. A eficácia otimizadora, que consiste em orientar a interpretação dos preceitos e dos atos concretos que conformam uma ordem jurídica, no sentido de dar a mais ampla, profunda e completa aplicação possível a seu conteúdo de valor.

4. A eficácia sistêmica, que consiste em interconectar todos os preceitos e atos concretos informados pelo mesmo princípio, como que conformando uma superestutura abstrata, que lhes infunde unidade e coerência. ${ }^{8}$

5. A eficácia integrativa, que consiste em preencher eventuais lacunas da ordem jurídica.

Os princípios podem se hierarquizar formalmente, enciclopedicamente ou axiologicamente, conforme a estruturação de cada ordem jurídica de que se trate.

No caso da ordem jurídica brasileira, hierarquizam-se, formalmente, os princípios constitucionais e os princípios infraconstitucionais.

7 Esta é a visão que informa, como é sabido, toda moderna teoria dos direitos fundamentais, lembrando GOMES CANOTILHO, a respeito uma elucidativa passagem de K. KRUGER “que, na época atual, se assistia à deslocação da doutrina dos 'direitos fundamentais dentro da reserva da lei' para a doutrina da reserva de lei dentro dos direitos fundamentais" (Direito Constitucional, Coimbra, Almedina, 1991, $5^{2}$ edição, p. 192

8 A respeito de eficácia mediata dos princípios, do autor, o artigo já mencionado, Princípios da Licitaçāo, publicado em julho de 1995, in Boletim de Direito Administrativo, São Paulo, Nova Dimensāo Jurídica, $\mathrm{n}^{\circ} 7$, ano XI. 
Hierarquizam-se, também, enciclopedicamente, conforme a abrangência dos valores e finalidades que contenham, distinguindo-se princípios fundamentais, princípios gerais e princípios setoriais".

Hierarquizam-se, ainda, axiologicamente, neste caso segundo a importância juspoliticofilosófica que apresentem, como, por exemplo: a prelazia do princípio da vida humana sobre o da propriedade; o da preeminêncìa da dignidade humana sobre o da publicidade; a primazia do valor social do trabalho sobre a liberdade de mercado etc.

O método de hierarquização adotado neste breve estudo da principiologia informativa das recentes normas de Responsabilidade na Gestão Fiscal, como a denomina a ementa da Lei Complementar $n^{\circ} 101$, de 4 de maio de 2000, será, porém, basicamente o formal, por ser mais simples e menos polêmico e por bastar para que se possa, com ele, estruturar uma orientação para os seus intérpretes e aplicadores, que seguramente será ampliada e aperfeiçoada à medida em que venham à luz monografias dos publicistas dedicados ao Direito Financeiro.

\section{Princípios informativos do direito financeiro}

É o próprio conceito de Direito Financeiro que, desde logo, introduz a orientação básica do intérprete para aplicar os princípios gerais e setoriais que lhe são pertinentes, por isso, convém tê-lo presente, como o conjunto de princípios, preceitos e atos concretos que regem as atividades administrativas do Estado e das demais pessoas incumbidas da gestão de recursos públicos financeiros e patrimoniais, ditadas pelo interesse público legal, legítima e licitamente definido pelos órgãos competentes.

Com esse conteúdo, a situação taxinômica do Direito Financeiro é a de ramo especializado do Direito Administrativo, concentrado no aspecto financeiro-orçamentário das atividades administrativas públicas, e, por isso, de sub-ramo do Direito Público, que rege todas as relações de poder que se estabelecem entre o Estado e a sociedade e, como tal, submetido ao Direito Constitucional, que, por sua vez, demarca integralmente os limites formais e materiais dessas relações de poder.

Como se observa, pelo conceito acima oferecido, os princípios assomam em posição destacada, cumprindo, portanto, identificá-los, categorizá-los, enunciá-los e estudá-los. São, aqui, identificados quinze, como de maior relevância; por óbvio, sem exclusão de quaisquer outros, que possam ser acrescentados, numa listagem mais dilatada: fundamentais, gerais e, mesmo, setoriais, como, por exemplo, neste último caso, os referentes ao processo administrativo.

9 A Constituição, ela própria, adota essa classificação enciclopédica, como, por exemplo, para os princípios econômicos, distinguindo os fundamentais, do art. $1^{\circ}, \mathrm{IV}$, dos gerais, do art. 170 , e dos setoriais, disseminados por todo o Título VII, como os do abuso de poder econômico, art. $173, \S$ $4^{\circ}$; os dos serviços públicos concedidos, art. 175, parágrafo único, II, III e IV; o do fomento do turismo, art. 180, os da política urbana, art. 182 etc. 
Incidentes sobre todo o Direito Financeiro, são particularmente informativos, 3 principios fundamentais e 7 princípios gerais. Especificamente sobre as atividades próprias do Direito Financeiro, constantes da Lei Complementar $n^{\circ} 101$, de 4 de maio de 2000 , voltadas à responsabilidade na gestão fiscal, são enumerados e descritos 5 princípios setoriais. Todos, a seguir, tratados sucintamente.

\section{I - Princípios Fundamentais}

\section{Princípio Republicano}

O País está constituído como uma república, conceito originalmente oposto ao de monarquia, derivado da voz latina res publica, traduzido livremente como coisa comum, que se incorporou à Filosofia Política como um regime político em que se define um espaço público, distinto do privado, no qual são identificados e caracterizados certos interesses, também ditos públicos, que transcendem os interesses individuais e coletivos dos membros da sociedade e, por isso, passam a ter sua satisfação submetida a decisões, normativas e concretas, de agentes também públicos.

O princípio republicano, que já teve, outrora, mais destaque nas Cartas Políticas brasileiras, ${ }^{10}$ hoje está apenas implícito, nas cinco menções que lhe faz a de 1988 , a começar com a designação oficial do País, no art. $1^{\circ}$, caput, como República Federativa.

Sob este princípio, a gestão dos dinheiros e dos bens, que forem caracterizados como públicos, é atribuição do Estado, que a realiza segundo normas de conduta administrativa que ele próprio formula.

\section{Princípio Democrático}

Este princípio se refere à forma de governo, adotada por um Estado, seja republicano ou monárquico, que reconheça a origem do poder no povo, como a totalidade dos membros da sociedade aptos a manifestar a vontade política geral, e, em razão disso, estabeleça a igualdade de todos perante a lei, inclusive para proceder à escolha dos seus representantes, que deverão manifestar o poder do Estado de acordo com a vontade popular, a ser recolhida nos sufrágios e por outras formas de manifestação política admitidas na ordem jurídica.

O princípio democrático vem, também, implícito na configuração do Estado brasileiro, no art. $1^{\circ}$ caput, bem como na cláusula pétrea, que protege o voto direito, secreto, universal e periódico, no art. $60, \S 4^{\circ}$, II.

10 Os dispositivos simétricos ao do art. $60, \S 4^{\circ}$, da atual Carta, ou sejam: o art. 217 , $6^{\circ}$, da Constituição de 1946; o art. 50, $\S 1^{\circ}$, da Constituição de 1967; e o art. 47, $\S 1^{\circ}$, da Constituição de 1969 (Emenda $n^{\circ} 1$ ), todos consignavam a república, junto com a federaçāo, como limites materiais de emenda (cláusulas pétreas). 
Do mesmo modo, a gestão dos recursos e bens afetos ao Estado, por força do princípio democrático, deve obedecer à vontade popular, devidamente cristalizada em normas que garantam a fidelidade política dessa atuação.

\section{Principio Participativo}

Por ser gregário por natureza, o homem tende a integrar-se no grupo em que convive. No decorrer do processo histórico da pluralização da convivência, essa integração passa a envolver vários grupos, ou círculos convivenciais, que se formam em diversos setores e locais de atividade, como o trabalho, o clube, os esportes, a política, a igreja, o bairro, a rua e em tantos outros.

Por isso, é também normal, que cada indivíduo se sinta estimulado a participar nas decisões coletivas, que devam ser tomadas nos vários círculos de sua convivência e, dentre elas, as que dizem respeito a seus interesses políticos, indubitavelmente as que exercem maior atração para um grande número de pessoas, o que contribui para desenvolver, notadamente e com maior intensidade nesta Era da Informação, o sentido de cidadania e de responsabilidade pela coisa comum.

Por outro lado, a democracia que se exerce através da participação mínima, que é o sufrágio de mandatários populares para o desempenho de cargos políticos, e, no caso brasileiro, de legisladores e de governantes, nos três níveis federativos, se tem, mostrado insuficiente como instrumento de legitimação de condutas públicas, admitindo-se, cada vez mais, que possa ser exercida por outras formas de participação política.

Essas formas de participação, direta e semi-direta, que se dão no campo da legislação, da administração pública e da provocação judicial, encontram-se referidas tanto na Constituição como em várias normas infraconstitucionais, que, não obstante, para institui-las, não necessitarão de qualquer previsão constitucional específica, uma vez que a devolução de poder ao povo, o soberano nas democracias, será sempre possível e até desejável, desde que a própria Constituição não a condicione, como o faz no caso da autorização para referendo e da convocação de plebiscito, que ficam sob reserva de decisão do Congresso Nacional."

A participação política, como expressão da consciência social e cidadã, se constitui, ao lado da representação política, que, assim, é dela apenas um aspecto, como um princípio instrumental, voltado à plena realização da democracia, ou seja, não apenas para a escolha dos governantes, mas de como o povo pretende ser governado, daí sua menção destacada em vários dispositivos da Constituição, a começar pelo art. $1^{\circ}$, parágrafo único, que faz expressa referência ao exercício direto da democracia.

Ora, uma vez que o orçamento público é também um dos mais vigorosos instrumentos para a realização da democracia substantiva, é claro que qualquer

11 Art. 49, XV, CF. 
aplicação do princípio da participação, que seja adequada à tomada de decisão, ao acompanhamento e ao controle da gestão financeiro-orçamentária, concorrerá para o mesmo efeito legitimatório, em última análise, o diretamente visado na Lei Complementar $\mathrm{n}^{\circ} 101$, de 4 de maio de 2000.

A Lei de Responsabilidade Fiscal contém expressa referência à participação, assegurando a transparência (sic), mediante incentivo à participação popular $\mathrm{e}$, mais detalhadamente, à realização de audiências públicas durante os processos de elaboração e de discussão dos planos, leis de diretrizes orçamentárias e orçamentos (art. 48, parágrafo único).

\section{II - Princípios Gerais}

\section{Princípio da Legalidade}

A submissão do agir à lei, essência do princípio da legalidade, é exigida de todos apenas se determinada conduta ou inação estiverem nela prescritas, pois a regra geral para a sociedade é a liberdade de ação.

Para o Estado, todavia, a submissão de seu agir à lei é sempre exigida, pois o Poder Público não pode atuar, sob hipótese alguma, praeter legem, exigindo-se-lhe a vinculação da ação.

Em consequiência, a gestão financeira e orçamentária, como um aspecto particular da administração pública, se submete integralmente a este princípio, expressamente consignado como princípio geral constitucional, no art. 37, caput, e repetido, como princípio setorial da atividade de fiscalização contábil, financeira, orçamentária, operacional e patrimonial, no art. 70 , caput.

\section{Princípio da Legitimidade}

Como Estado Democrático de Direito, o Estado brasileiro está submetido, simultaneamente, a duas ordens de valores referenciais de ação: a vontade juridicamente positivada e a vontade democraticamente expressa.

A vontade juridicamente positivada é o campo da legalidade, tal como examinado, enquanto que a vontade democraticamente expressa é a definição soberana do interesse público e de como deva ser atendido pela ação do Estado, no campo da legitimidade.

Este princípio da legitimidade, essencial nas democracias, é que informa todas as atividades normativas do Estado, em especial, o instituto da discricionariedade, mediante o qual, por vezes, se autorizará a integração administrativa da vontade contida na norma legal, que esteja ainda carente de maior densificação, para que possa ser concretamente aplicada. 


\section{Princípio da Impessoalidade}

Este princípio tem uma tríplice acepção; todas, com grande riqueza de conteúdo.

A primeira tem o sentido de vedação à Administração de distinguir interesses de qualquer ordem, onde a lei não o fizer.

A segunda tem o conteúdo de vedação à Administração de perseguir interesses públicos secundários próprios, desvinculados dos interesses públicos primários, como tal definidos em lei. Neste caso, se enfatiza a natureza jurídica ficta da personalização do Estado, que, por isso, jamais deverá atuar em seu exclusivo benefício, mas sempre no da sociedade.

Uma terceira acepção, que apresenta ligeira diferença em relação à segunda, enfatiza que a Administração não pode dar precedência a esses interesses públicos secundários, que porventura tenha, enquanto pessoa administrativa, sobre quaisquer interesses finalísticos que lhe sejam cometidos pela ordem jurídica.

Como se pode observar, essas três vertentes confluem para definir a correta atuação do Estado, enquanto administrador, relativamente à sua indisponível finalidade objetiva, que é aquela expressa em lei, ou seja, uma ação sempre e totalmente despida de qualquer inclinação, tendência ou preferência subjetiva, mesmo em benefício próprio, o que levou Cirne Lima a afirmar que a boa administração é a que prima pela "ausência de subjetividade".

Este princípio, expresso no art. 37, caput, da Constituição, tem, assim, sob qualquer dos aspectos examinados, plena aplicação à gestão financeira e patrimonial.

\section{Princípio da Moralidade Administrativa}

A autonomia deste princípio, que não deve ser confundido com a moralidade tout court, nem, tampouco, com o conceito de moralidade média, decorre de seu sentido rigorosamente técnico, como reflexo dos conceito de boa e de má administração.

Para que o administrador vulnere este princípio, basta que administre mal os interesse públicos, o que poderá ocorrer de três modos: tanto através de atos com desvio da finalidade pública, para perseguir interesses que não são aqueles para os quais deve agir, como através de atos sem finalidade pública e, até mesmo, através de atos com deficiente finalidade pública, reveladores de uma ineficiência grosseira no trato dos interesses lhe foram afetos.

Este princípio, também constante do elenco constitucional do art 37, caput, é tão importante que o constituinte voltou a destacá-lo, para incluí-lo como fundamento autônomo para a postulação da ação popular, no art. $5^{\circ}$, LXXIII, além de ficar implicitamente referido em vários outros dispositivos, como, por exemplo, e ainda destacadamente, o que impõe sanções aos atos de improbidade administrativa, no art. $37, \S 4^{\circ}$, tendo, portanto, plena aplicação às atividades da administração financeiro-orçamentária tratadas na Lei de Responsabilidade Fiscal. 


\section{Princípio da Eficiência}

Recém-introduzido na Constituição, acrescentado ao rol de princípios explícitos do art. 37, caput, este princípio substantivo é o resultado de um aplicado trabalho de vanguarda da doutrina jurídica, desenvolvida desde meados do século $\mathrm{XX}$, ostentando nomes como Raffaele Resta e Guido Falzone, no sentido de transcender o conceito de poder-dever de administrar, afirmado pela administração burocrática, empenhada em lograr apenas a eficácia jurídica, para estabelecer, como um passo adiante, o dever de bem administrar, que é hoje respaldado pelos novos conceitos gerenciais, voltado à eficiência da ação administrativa pública.

O conceito de eficiência, dantes vago ou simplesmente confundido com o da eficácia, ganhou precisão com a Revolução Industrial, quando começou a ser definido como a relação entre um produto útil e aquele teoricamente possível com os meios empregados, daí passando à Economia, na qual se aproximou e até certo ponto se confundiu com o conceito de produtividade, ou seja, de uma relação mensurável ou estimável entre produto e insumos, daí chegando à administração privada e, finalmente, à pública.

Com o desenvolvimento da nova concepção da administração pública gerencial, que deu um passo além da administração burocrática, asseverou-se não ser bastante a prática de atos que simplesmente estejam aptos a produzir os resultados juridicamente dele esperados, o que apenas atenderia ao conceito clássico de eficácia, exigindo-se, mais ainda, que esses atos sejam praticados com certas qualidades intrínsecas que possibilitem lograr-se o melhor atendimento possivel das finalidades que deve, por lei, atender.

Essas qualidades de excelência exigiveis, podem ser tão numerosas e detalhadas quantas seja possível submeter a controles efetivos, bastando, para defini-las, que existam parâmetros legalmente estabelecidos, tais como, numa relação meramente exemplificativa, os que poderão ser deduzidos sob critérios de tempo, de quantidade ou valor de recursos utilizados, de generalidade do atendimento ou das respostas dos usuários (feedback), sempre objetivos, pois o importante é que o conceito jurídico de eficiência jamais possa ser subjetivo, de outro modo apenas se substituiria o arbítrio na administração pelo arbítrio no exercício do controle.

Entendida a eficiência como a melhor realização possivel da gestão dos interesses públicos, em termos de plena satisfação dos administrados com os menores custos para a sociedade, apresenta-se ela, simultaneamente, na ação administrativa pública, como um atributo técnico da administração, como uma exigência ética a ser atendida, no sentido weberiano de resultados, e como uma característica jurídica, que também pode ser cobrada, de boa administração dos interesses públicos.

Mas, sobretudo e como nota de destaque, uma vez consagrado constitucionalmente, o dever de eficiência do setor público, de atuar como bom gestor de interesses da sociedade, sempre que possa,ser objetivamente aferível, passou a ser um direito difuso da cidadania, um tema que, de tão importante, é retomado adiante, no mesmo artigo, pelo próprio legislador constitucional, sublinhando, inequivocamente, a importância que lhe conferiu, ao determinar que o legislador o regule, especialmente quanto à disciplina das reclamações relativas à prestação de serviços públicos em 
geral, ao acesso a registros e informações sobre atos de governo e à representação contra o exercício negligente ou abusivo de cargo, emprego ou função na Administração Pública (art. $37, \S 3^{\circ}$ ).

À vista do exposto, no que respeita à Lei de Responsabilidade Fiscal, a informação do princípio estudado é amplíssima, pois o que se pretende, em última análise, é recobrar e manter o máximo de eficiência na gestão financeira orçamentária, sob certo aspecto, repetida na menção à economicidade, como princípio setorial, no art. 70, caput, da Constituição.

\section{Princípio da Continuidade}

Considerando-se em conjunto as atividades do Estado enquanto administrador, inclusive como gestor financeiro e orçamentário, todas elas se supōem definidas e a ele cometidas pela ordem jurídica, sob cláusula de indispensabilidade, uma vez que o legislador as considerou necessárias à satisfação dos interesses públicos confiados à Administração, o que as torna, para ela, em regra, indisponíveis.

Disso resulta, que qualquer solução de continuidade que a Administração possa causar ou permitir que se cause à regularidade dessas atividades, afronta a ordem jurídica, salvo se a própria lei a autorizar ou, é claro, resultar de caso fortuito ou força maior, que escapem à previsão normal do bom administrador.

Como no já clássico ensinamento de José Cretella Júnior, não é, porém, necessário que a atividade da Administração seja permanente, só é preciso que seja regular, de acordo com sua natureza e com a lei que a categorizou como atividade pública.

O exemplo mais eloqüente de aplicação do princípio da continuidade está no exercício do poder de polícia, incompatível com qualquer paralisação, bem como na prestação de serviços públicos, que se sujeitam a uma cláusula constitucional que impõe a prestação de serviços adequados (art. 175, parágrafo único, IV).

A continuidade, considerada sob o ponto de vista institucional, é um princípio que se impõe e se garante pela própria continuação da existência do Estado, pouco importando a substituição periódica dos governos.

Eis a importância capital da continuidade nas atividades da gestão financeira e orçamentária, porque a sociedade, tem na sua fluência regular e segura, a mais expressiva garantia material das prestações estatais, pela disponibilidade adequada e assegurada, que enseja, dos recursos públicos necessários, segundo suas prioridades planejadas, um princípio tão manifesto que, embora não tenha também sido explicitado no art. 37, caput, da Constituição, pode nele ser considerado implícito.

\section{Principio da Publicidade}

O Direito é, por definição, um sistema de normas de conduta social gerais, abstratas e previamente conhecidas, o que está a indicar que a publicidade é o requisito lógico para que qualquer norma possa ser antecipadamente conhecida e, 
por extensão e do mesmo modo, o seja a sua execução de ofício pelo Estado. visando à produção de quaisquer outros atos, abstratos ou concretos, uma vez que só por ela se poderá ter ciência, se tais atos obedeceram ao que em abstrato para ele se prescreveu e, submetê-los a controle.

Por isso, no Direito Público e no Administrativo, em particular, o princípio da publicidade assoma como o mais importante princípio instrumental, indispensável para a sindicabilidade da legalidade, da legitimidade, e da moralidade da ação do Poder Público, pois será pela transparência dos seus atos, ou, como mais adequadamente expressado, por sua visibilidade, que se tornará possível constatar a sua conformidade ou desconformidade com a ordem jurídica e, em consequiência, serem exercidas as várias modalidades de controle nela previstos, para promover a desejada responsabilidade.

A publicidade, no Direito Público, considerada agora sob outro ângulo, constitui-se também como um direito fundamental do administrado, extensivo às entidades de sua criação, uma vez que, sem ela, tornar-se-ia impossível controlar a ação estatal, e, em última análise, uma falácia, a sustentação dos direitos fundamentais e do próprio Estado de Direito.

Assim, a publicidade rege, necessariamente, o elemento formal do ato administrativo, o que lhe confere plena aplicação em seu ramo Financeiro, em que prepondera a formalidade.

A Lei de Responsabilidade Fiscal contempla, em inúmeros dispositivos, a necessidade de dar publicidade aos atos relativos à gestão financeiro-orçamentária, como nos exemplos colhidos.

A Lei de Responsabilidade Fiscal contempla, em inúmeros dispositivos, a necessidade de dar publicidade aos atos relativos à gestão financeiro-orçamentária, como nos exemplos colhidos.

A relação dos instrumentos de transparência da gestão fiscal: planos, orçamentos, leis de diretrizes orçamentárias, prestações de contas, o respectivo parecer prévio, o relatório resumido da execução orçamentária, o relatório da gestão fiscal e as versões simplificadas desses documentos (art. 48).

O franqueamento das contas apresentadas pelo Chefe do Poder Executivo, durante todo o exercício, à disposição no respectivo Poder Legislativo e no órgão técnico responsável pela sua elaboração, para consulta e apreciação pelos cidadãos e instituições da sociedade (art. 49).

Os requisitos específicos de escrituração contábil, sem prejuízo da satisfação das normas de contabilidade pública estabelecidas na Lei $\mathrm{n}^{\circ} 4.320 / 64$, salvo quando excludentes (art. 50).

A manutenção de sistema de custos, que permita a avaliação e acompanhamento da gestão orçamentária, financeira e patrimonial (art. $50, \S 3^{\circ}$ ).

A consolidação de contas nacionais (art. 51).

A ampla divulgação, devida, dos resultados da apreciação das contas, julgadas ou tomada, dos Chefes de Poder Executivo, inclusive dos agentes relacionados no art. 20 (art. 56, $\S 3^{\circ}$ ). 


\section{III - Princípios Setoriais}

\section{Princípio do Planejamento}

O planejamento, em sua expressão mais simples, é disposição racional de meios para atingir objetivos.

Seu conceito é relativamente moderno, tendo evoluído do âmbito técnico, onde teve origem, a partir da observação dos métodos de decisão dos estados-maiores, no curso do século XVIII, para o âmbito político, quando começou a ser empregado para racionalizar o desdobramento de outras ações do Estado para atingir objetivos complexos ou de longo prazo, para, finalmente, alcançar o âmbito jurídico, quando se iniciou a discussão de sua compatibilidade com os princípios liberais, que já estavam insculpidos nas Constituições do século XIX, como os que asseguravam liberdades individuais de escolha de atividade ou profissão e de atuar no mercado.

$O$ surto de ideologias, que varreu a Europa e o mundo na primeira metade do século XX, desdobrou o planejamento em dois tipos: de um lado, o planejamento dispositivo, denominado simplesmente planejamento, que pode ser compatibilizado com a democracia e com a economia de mercado, reservando-se ao Estado o papel de fomento público, e, de outro lado, o planejamento impositivo, ou planificação, através do qual o Estado ditaria não só as suas próprias atividades, como as de toda a sociedade, nos campos econômico e social.

A História demonstrou, com o fracasso das experiências nazistas, fascistas, comunistas e socialistas de todo o gênero, que marcaram boa parte do Século XX, que o planejamento é um instrumento absolutamente indispensável para racionalizar a ação do Estado, mas absolutamente inútil e perigoso para tentar racionalizar a ação de uma sociedade livre.

Assente, hoje, a premissa da compatibilidade do planejamento com as garantias liberais e a democracia, passou a ser adotado o planejamento estatal, com sentido impositivo apenas para o setor público, e dispositivo, para o setor privado, de modo que as ações públicas, a cargo do Estado, necessitam de transfundi-lo numa norma legal, para que the seja imposta a desejada racionalidade.

Assim é que as Constituições, como, no caso, a brasileira, cuidam de incorporá-lo à ordem jurídica através de leis orçamentárias: o plano plurianual, a lei de diretrizes orçamentárias e a lei orçamentária anual (art. 165).

A aplicação desse princípio aos orçamentos, exigiu, mais, que se abandonasse a visão tradicional do orçamento desempenho, que servia apenas para acompanhar as despesas previstas, para desenvolver o orçamento programa, destinado a planejar coercitivamente as ações do Estado com expressão financeira.

O princípio do planejamento está presente, entre outros dispositivos constitucionais esparsos, notadamente no art. 165 , especialmente no caput, e ainda nos seus $\S \S 4^{\circ}, 5^{\circ}$ e $7^{\circ}$; no art. $166, \S 4^{\circ}$; no art. 167 , VI, VII, IX, $\S \S 1^{\circ}$ e $2^{\circ}$; e no art. 169 , I e II.

$\mathrm{Na}$ Lei de Responsabilidade Fiscal, a força informativa do princípio do planejamento está amplamente disseminada em vários dispositivos, como os que tratam 
da Lei de Diretrizes Orçamentárias (art. $4^{\circ}$ e $5^{\circ}$ ), dos objetivos das políticas públicas (art. $4^{\circ}, \S 4^{\circ}$ ), da reserva de contingência (art. $5^{\circ}$, III) e da programação financeira (art. $\left.8^{\circ}\right)$.

\section{Princípio do Equilíbrio}

Este princípio está vocacionado à sustentação de uma qualidade indispensável na gestão financeiro-orçamentária, que é a relação estável entre os elementos fundamentais do crédito público, das despesas públicas e do endividamento público.

"Por mais óbvia que seja a noção de que todo o orçamento deve ser equilibrado, o fato é que isso não está expressamente dito em norma alguma", observou Adilson Abreu Dallari ${ }^{12}$, de modo que, também, sob mais este aspecto, é bem-vinda, a Lei de Responsabilidade Fiscal, por manifestar este princípio de equilíbrio das contas públicas em dispositivos cruciais.

São nítidos exemplos de aplicação deste princípio a exigência do equilíbrio entre receitas e despesas na elaboração da Lei de Diretrizes Orçamentárias, dispondo para que, progressivamente, sejam alcançadas e possam ser satisfeitas as metas de superávit primário (art. $4^{\circ}, \mathrm{I}, a$ ); as regras relativas à renúncia de receitas (art. 14, I), a ação que aumente despesas (art. 16) e as regras alusivas aos sistemas previdenciários próprios dos entes da Federação (art. 69).

\section{Princípio do Controle}

Para submeter-se à juridicidade plena, ou seja, à legalidade, à legitimidade e à licitude (moralidade) de suas ações, a Administração Pública, como braço executivo do Estado, tem o seu poder contido por duas técnicas juspolíticas: a limitação e o controle do poder.

A limitação atua pelas restrições que se impõem à atuação do Estado em face das liberdades e dos direitos dos administrados e de suas próprias regras de competência, sintetizada nos princípios da legalidade, da legitimidade e da moralidade administrativa, tratando-se, portanto, de uma contenção estática.

As normas orçamentárias, e por isso que devem ser formalmente leis, que condicionam o exercício das competências administrativas, são exemplos de limitações.

Distintamente, o controle atua pela ação admitida contra a ação do Estado (reação), sempre que seja necessário sustentar o primado da ordem jurídica, preventivamente ou corretivamente, tratando-se, portanto de uma contenção dinâmica.

$\mathrm{Na}$ Lei de Responsabilidade Fiscal o princípio do controle está sempre presente, demonstrando a preocupação permanente do legislador em instrumentá-lo o mais amplamente possível, até mesmo para romper a inércia das práticas tradicionais, 
alinhando várias modalidades, a serem desenvolvidas pela própria Administração e pelo Poder Legislativo, diretamente ou por meio de Tribunais ou Conselhos de Contas, que são seus órgãos auxiliares.

Sobre essas modalidades administrativas, paira o controle jurisdicional, exercido pelo Poder Judiciário, nos casos em que lhe caiba dar a última palavra em termos de juridicidade, bem como a provocação onimoda do controle, atribuída às funções essenciais à justiça, dentre as quais ressalte-se o Ministério Público, nos casos em que seu impulso esteja previsto, e, à sociedade, em geral, nos casos em que é admitida, especialmente na hipótese do art. $74, \S 2^{\circ}$, da Constituição.

O controle financeiro orçamentário exercido pelos Tribunais e Conselhos de Contas, especificamente aparelhados para esse fim, é tradicionalmente realizado $a$ posteriori, no que respeita, rigorosamente, a vedação de interferências, constitucionalmente previstas, de um Poder sobre o outro ${ }^{13}$.

A Lei de Responsabilidade Fiscal inova, contudo, uma variedade de controle contemporâneo, concomitante, ou simultâneo ao desenvolvimento da gestão, apresentando-se, assim, como uma original modalidade preventiva.

Trata-se, esse controle contemporâneo, como foi batizado, do mecanismo de alerta, instituído no art. $59, \S 1^{\circ}$, da Lei de Responsabilidade Fiscal, pelo qual, os Tribunais de Contas, através de ato administrativo declarativo de natureza cautelar, e, de responsabilidade de seus plenários, por implicarem em relações substantivas entre Poderes, deverão chamar a atenção dos gestores, que estão relacionados no art. 20 , para as situações de risco de irregularidades e de infraçōes que estão elencadas nos cinco itens do referido art. $59, \S 1^{\circ}$.

Além dessa modalidade original, a lei de responsabilidade Fiscal dispõe sobre uma alentada gama de instrumentos específicos de controle, incluídos o controle de custos e o de resultados.

\section{Principio da Responsabilidade}

Responder pela ilegalidade praticada é dever tão antigo quanto o próprio Direito. Desde as mais primitivas comunidades já se procurava identificar o violador das normas para aplicar-lhe sanções.

No Direito Público a responsabilidade é sua pedra angular, porque, se todos devem responder por seus atos, com muito maiores razóes deve fazê-lo o Estado, que é o responsável direto pela ordem jurídica, e, consequiêntemente, devem também os seus agentes, que assumiram livremente o múnus de executar as várias e distintas funções que essa mesma ordem jurídica impõe.

Para desempenhar as atribuições de administração pública, cometidas órgãos e agentes do Estado, lhes são atribuídas competências para agir, mas a cada uma destas, correspondem proporcionais responsabilidades no agir: quanto maior e mais grave a competência, maior e mais grave a responsabilidade de quem a exerce. 
No Direito Administrativo, a responsabilidade geral, que é a de agir segundo o comando da lei, se acresce da responsabilidade específica, de não deixar de agir segundo o comando da lei, uma vez que administrar é aplicar a lei de ofício.

Agrava-se, portanto, a responsabilidade do agente, no Direito Administrativo, pois não se trata apenas de, quando agir, submeter-se à lei, mas de sempre agir, quando e como a lei o prescreva.

Observe-se que o principio da responsabilidade, de natureza substantiva, gera o dever derivado de prestar contas, o que pressupõe o poder de tomar contas, que vem a ser a substância do conexo, mas não menos importante, princípio instrumental da sindicabilidade.

Com efeito, se não for possível perquirir-se se ocorreu descumprimento da lei na ação administrativa, e, por extensão, se está ocorrendo ou, mesmo, se há iminência de ser descumprida, aquele princípio axiomático de todo o Direito ficaria inane e frustro.

Assim, a sindicabilidade implica na possibilidade jurídica de submeter-se qualquer lesão de direito e, por extensão, as ameaças de lesão de direito a algum tipo de controle.

É indubitável que a gestão administrativa financeira e orçamentária deve ser sindicável, o mais extensa e profundamente possível, para que o princípio da responsabilidade seja também o mais ampla e rigorosamente aplicável. E este é todo o propósito, como o próprio título o destaca em epígrafe, da Lei Complementar $\mathrm{n}^{\circ}$ 101, de 4 de maio de 2000: lograr a responsabilidade na gestão fiscal, como se pode acompanhar pelos exemplos seguintes.

A cominação de não autorizadas, irregulares e lesivas ao patrimônio público, em caso de geração de despesas ou de assunção de obrigações que não se submetam aos requisitos substantivos e formais estabelecidos (arts. 15, 16 e 17).

A cominação de nulidade do ato que provoque aumento de despesa com pessoal, que desatenda às exigências formais da lei e aos limites materiais estabelecidos (art. 21).

A cominação específica de nulidade do ato que aumente despesa com pessoal nos cento e oitenta dias anteriores à expiração do mandato do titular de Poder ou de órgão financeiramente responsabilizável, que são os enumerados no art. 20 (art. 21, parágrafo único).

A vedação, dirigida ao Banco Central, de emitir títulos da dívida pública a partir de dois anos após a publicação da Lei Complementar (art. 34).

A vedação de realização de operações de crédito entre pessoas administrativas (referidas), admitidas algumas exceções (art. 35), inclusive operações expressamente equiparadas (art. 37).

As vedações ao Banco Central do Brasil, de compra de título de dívida, na data de sua colocação no mercado, de permuta, ainda que temporária, ou operação cujo efeito final equivalha à permuta, de título de dívidas de ente da federação (art. 39).

Suspensão de acesso a novos créditos ou financiamentos, do ente da Federação, cuja dívida que tiver sido honrada pela União ou por Estado, em decorrência de garantia prestada em operação de crédito (art. 40, §10). 
A vedação ao titular de Poder ou órgão responsabilizável, conforme relação do art. 20, de contrair obrigação de despesa nos dois quadrimestres finais de seus respectivos mandatos, que não possa ser cumprida integralmente dentro dele, ou que tenha parcelas a serem pagas no exercício seguinte sem que haja suficiente disponibilidade de caixa para este efeito (art. 42).

\section{Principio da Responsividade}

Contudo, se responder pela ilegalidade é dever tão antigo quanto o próprio Direito, responder pela ilegitimidade é tão recente quanto a consolidação histórica da democracia na cultura ocidental.

O princípio da responsividade vem, por isso, complementar o principio da responsabilidade e ampliar-lhe os efeitos, além da legalidade estrita, para inspirar e fundar todo um novo capítulo sancionatório do Direito Administrativo, voltado à preservação do princípio democrático e da legitimidade, que dele decorre.

$\mathrm{Na}$ verdade, tomada em seu sentido mais dilatado, a responsividade, tal como surgiu nos estudos sobre a participação política, é princípio instrumental da democracia, uma vez que se destina a salvaguardar a legitimidade, ou seja, a conciliar a expressão da vontade popular, democraticamente recolhida, com a racionalidade pública. ${ }^{14}$

Por isso, apresentada como complemento atualizador da responsabilidade, a responsividade é a reação governamental que deve ser esperada à enunciação da vontade dos governados, o que, "Em tema de Governo, isto é muito do que trata a democracia", como remarca Roland Pennock, ao tratar de situar cientificamente a responsiveness ${ }^{15}$, escrevendo ainda em $1979^{16}$.

Foi neste sentido que tive também ocasião de empregar a expressão responsividade, considerando-a que está para o Estado Democrático, assim como a responsabilidade está para o Estado de Direito.

São, nesta linha de idéias, responsabilidade e responsividade, complementares para a construção de um conceito integrado de Estado Democrático de Direito, tal como inaugurado pela Lei Básica de Bonn e difundido nas Constituições contemporâneas ${ }^{17}$.

14 Como deixei alhures consignado, a partir desse dilema é que nasce uma das mais angustiantes tensões da democracia contemporânea, "entre o elitismo, que propugna o governo da razāo, ainda que legitimamente destravejado, e o populismo, que propugna o govemo do desejo, ainda que racionalmente inepto". (DIOGO DE FIGUEIREDO MOREIRA NETO, Direito da Participação Política, Rio de Janeiro, ed. RENOVAR, 1993, p. 38).

15 Responsive, a. [LL., responsiva, f., an answering; L. responsus, pp. of respondere, to respond]...2. reacting easily or readily to suggestion or appeal; as a responsive audience.

16 ROLAND PENNOCK, Democratical Political Theory, nº Jersey, University Press, 1979, p. 261 (n/trad.).

17 Para aprofundamento da relação entre a responsividade e participação democrática, o Capítulo II, do livro citado na Nota supra, Direito da Participação Política, de nossa lavra, escrito entre os anos de 1990 e 1991 (V. p. 2). 
Com isso, pode-se afirmar que, nas democracias contemporâneas, a responsividade é hoje um dever jurídico autônomo dos agentes do Poder Público, sempre que disponham de quaisquer escolhas administrativas, que devam exercer, para atender (responder) adequadamente às demandas da cidadania, regularmente manifestadas.

O termo responsividade também é usado intercambiadamente com uma outra expressão que vem da língua inglesa, accountability ${ }^{18}$, que, não obstante a existência da contraparte vernácula ${ }^{19}$, vem sendo utilizada, como difundido anglicismo, até mesmo em debates da Câmara dos Deputados ${ }^{20}$.

A respeito, depois de registrar a indecisão terminológica, Carlos Pinto Coelho da Motta (et alii), também conclui, no mesmo sentido, que “... esse conceito deverá realmente ser aperfeiçoado como questão de democracia, trazendo nesse percurso a inevitável necessidade de desenvolvimento das estruturas burocráticas e dos controles, para atendimento às obrigações do Estado; bem como de uma delimitação mais exata da discricionariedade administrativa, financeira e contábil dos entes políticos, em todos os níveis, notadamente o municipal" ${ }^{21}$.

Efetivamente, acompanhando o ilustre autor, se a responsividade democrática já é devida a partir dos estamentos legislativos do Estado, é nos meandros da aplicação discricionária que se aninha a expressão da legitimidade na ação administrativa, o que, sem dúvida, representa o maior desafio ao novo tipo de controle a ser desenvolvido, uma vez que se imbrica profundamente com o controle da discricionariedade. $^{22}$

Finalmente, acrescente-se, a sindicabilidade da responsividade dependerá também da qualidade do que se tem denominado de transparência da gestão administrativa financeiro-orçamentária, que, como já se lembrou, estaria mais bem denominada de visibilidade, pois o que se pretende, afinal, é torná-la pública, manifesta, visivel, a quem quer que deva ou queira conhecê-la.

Por isso, a publicidade é instrumental, tanto para a responsabilidade quanto para a responsividade, destacando-se, na Lei de Responsabilidade Fiscal, os dispositivos que adequadamente a aperfeiçoam, já referidos.

18 Accountability, $\mathrm{n}^{\circ}$ the state of being accountable, responsible, or liable; accountableness. Webster Dictionary of the English Language, Encyclopedic Edition, New York, Webster's Press, 1969, p.13.

19 Cf. verbete responsivo, in Novo Dicionário da Língua Portuguesa, AURELIO BUARQUE DE HOLLANDA FERREIRA, Rio de Janeiro, Nova Fronteira, 1986, p. 1.496.

20 Dessa particularidade, a respeito do uso do termo na audiência pública, que teve lugar na Comissão Especial da Câmara dos Deputados, em que se debateu o Anteprojeto, que viria ser convertido na Lei ${ }^{\circ} 8.666 / 93$, dá-nos conta a nota 28 , da obra Responsabilidade Fiscal, um trabalho, ao que consta ao Autor, que foi o primeiro a vir a lume sobre a Lei Complementar $n^{\circ} 101$, de 4 de maio de 2000, de autoria de CARLOS PINTO COELHO DA MOTTA, JAIR EDUARDO SANTANA, JORGE ULYSSES JACOBY FERNANDES e LÉO DA SILVA ALVES, Belo Horizonte, Del Rey, 2000.

21 CARLOS PINTO COELHO DA MOTTA et alii, op. cit., p. 43.

22 V. DIOGO DE FIGUEIREDO MOREIRA NETO, Legitimidade e Discricionariedade, Rio de Janeiro, Ed. Forense, 3* edição, 1998. 


\section{CONCLUSÕES}

Algumas observações vêm aqui apresentadas apenas à guisa de conclusões, ainda porque seria prematuro adiantá-las antes dos estudos preliminares que, como este, vêm sendo promovidos; do maior amadurecimento proporcionado pela doutrina autorizada e, sobretudo, do teste da experiência.

Para o êxito, que se espera, desse avanço institucional que está vivendo o País, será necessária a convergência dos esforços do Poder Público com a colaboração da sociedade.

O que a Lei Complementar $\mathrm{n}^{\circ} 101$, de 4 de maio de 2000, pretende introduzir no País é, porém, muito mais do que anuncia em sua epígrafe: tornar efetiva a responsabilidade fiscal. É, sobretudo, uma mudança de hábitos políticos, marcando a desejada passagem do patrimonialismo demagógico, para o gerenciamento democrático.

Mas a responsabilidade, bem como a responsividade, sem sindicabilidade, não se apuram; a sindicabilidade sem publicidade, não tem sentido; e todas, sem a responsabilização, ou seja, sem processos adequados conducentes à aplicação de sançöes, apenas mais frustram a sociedade.

Chega-se, assim, à inevitável observação, esta sim, proposta como conclusiva, por ser metodológica, de que o esperado êxito só se alcançará pelo efetivo emprego dos instrumentos de responsabilização, e não só os de lege lata, contidos na Lei examinada e na legislação sancionadora vigente, política, penal, administrativa e civil, como os de lege ferenda, que contemplam especificamente a responsabilidade fiscal e que se desenham no Projeto de Lei $n^{\circ}$ 621/99, que insere no Código Penal um Capítulo IV - Dos Crimes contra as Finanças Públicas, com novos típicos criminais; na Lei $n^{\circ} 1.079$, de 10 de abril de 1950 , que trata dos crimes de responsabilidade, com novas condutas puníveis; e, no Decreto-lei $n^{\circ} 201$, de 27 de fevereiro de 1967, com novos típicos de crimes de responsabilidade de Prefeitos.

Uma última reflexão: pode parecer que, com a Lei de Responsabilidade Fiscal, se trate apenas de galgar mais um degrau no desenvolvimento político deste País, o que já seria bom. Mas não é só isso: as gigantescas dimensōes geográficas, econômicas e sociais do Brasil, com seus correlativos titânicos problemas, exigem, urgentemente, esta mudança de hábitos políticos. Não há mais como procrastinar as providências que são possíveis de serem tomadas, como o são as da Lei de Responsabilidade Fiscal, pois a opção que nos fica, como no pensamento de Gustave le Bon, que serve de epígrafe para este ensaio, acaba sendo entre a responsabilidade ou a anarquia. 


\section{O Autoritarismo e a Ordem Constitucional no Brasil}

\section{José Ribas Vieira}

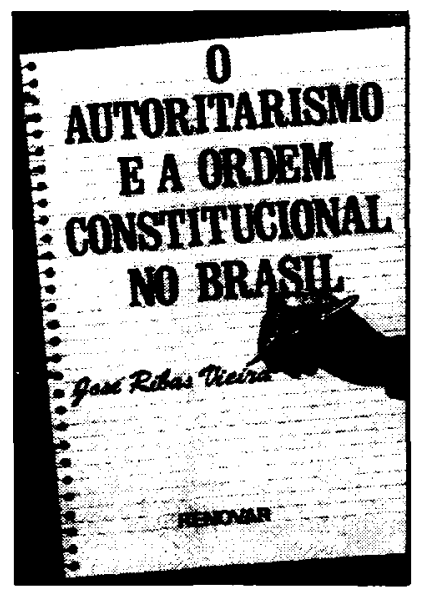

Esta obra assume a postura de falência de um Estado de Direito. A permanente restriçāo das garantias de direitos individuais e da inexistência de mecanismos de proteção contra os abusos do poder de Estado no país estimulou o autor a utilizar categorias de Estado de exceção (Marx/Poulantzas) e hegemonia (Gramsci) para interpretar a experiência constitucional brasileira. Este livro serve de instrumento prático de formação e conscientização dos estudiosos do Direito, representando em contraponto as obras tradicionais publicadas no campo da Teoria Geral do Estado/Direito Político no país.

Ref. 0011

Form. 14x21

Brochura

1988

\section{Obras Completas de Orlando Bitar Estudos de Direito Constitucional e Direito do Trabalho}

\begin{abstract}
Por sua profundidade erudita e por seu alcance crítico no campo da filosofia jurídica e do direito constitucional moderno, Orlando Bitar é um dos mais abalizados e ilustres publicistas deste pais. Logo às primeiras páginas deste admirável trabalho - A Lei Fundamental de Bonn e o Sistema Parlamentar da República Federal Alemã - o leitor pressente encontrar-se diante de um espírito percuciente e inquisitivo, que estudou com porfiada aplicação o que de melhor se produziu na Alemanha.
\end{abstract}

Ref. 0107

2 volumes

Encadernado

Form. 16x23

1.202 págs. 1996

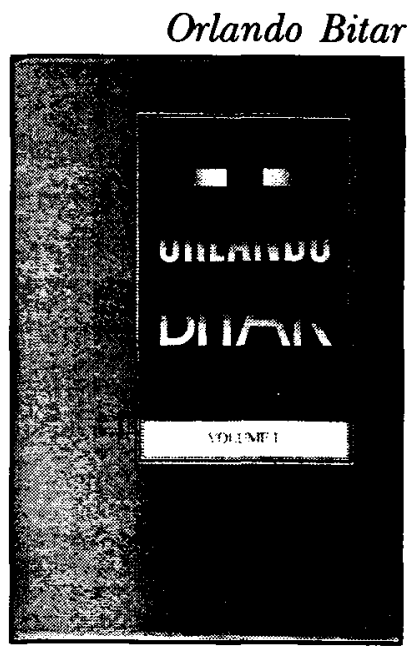

